\title{
Relevansi Persepsi Pendidikan KH. Hasyim Asyari dan Dekadensi Moral
}

\author{
Amrina Rosyada, Hudaidah \\ Universitas Sriwijaya \\ amrinarosyada62@gmail.com \\ hudaidah@fkip.unsri.ac.id
}

\begin{abstract}
Abstrak
KH. Hasyim Asyari merupakan salah satu pahlawan pendidikan Indonesia yang dikenal sebagai pembangun organisasi islam terbesar yaitu Nahdatul Ulama atau NU. Penelitian ini dilatarbelakangi oleh problematika yang terjadi di Indonesia yaitu penurunan tingkat moralitas. Penelitian ini memiliki tujuan mengulas bagaimana pendidikan berdasarkan persepsi KH. Hasyim yang menitikberatkan kepada moral atau etika. Metode yang digunakan dalam penelitian ini adalah penelitian kepustakaan yang bersumber dari publikasi ilmiah berupa artikel, skripsi, makalah dan hasil penelitian lain yang berkaitan dengan fokus penelitian. Pemikiran pendidikan KH. Hasyim Asyari tertuang di salah satu karya monumentalnya, yaitu kitab Adab al Alim wa al Muta'allim. Kitab ini berisi signifikasi pendidikan, tugas dan tanggung jawab seorang murid, serta tugas dan tanggung jawab seorang guru. Dalam hal ini, tugas dan tanggung jawab murid maupun guru diterjemahkan sebagai pendidikan moral yang harus dipenuhi saat pembelajaran dan merupakan satu-kesatuan dalam keseluruhan aspek yang harus dijalani seorang murid selama menempuh pendidikan.
\end{abstract}

Kata Kunci: Pendidikan; Moral; KH. Hasyim Asyari

\begin{abstract}
$\mathrm{KH}$. Hasyim Asyari is one of the heroes of Indonesian education who is known as the builder of the largest Islamic organization, namely Nahdatul Ulama or NU. This research is motivated by the problems that occur in Indonesia, namely the decline in the level of morality. This study has the aim of reviewing how education is based on the perception of KH. Hasyim who focuses on morals or ethics. The method used in this research is library research sourced from scientific publications in the form of articles, theses, papers and other research results related to the research focus. Educational thinking KH. Hasyim Asyari is contained in one of his monumental works, namely the book of Adab al Alim wa al Muta'allim. This book contains the significance of education, the duties and responsibilities of a student, as well as the duties and responsibilities of a teacher. In this case, the duties and responsibilities of students and teachers are translated as moral education that must be fulfilled during learning and is an integral part of all aspects that must be lived by a student during education. Keywords: Education; Moral; KH. Hasyim Asyari.
\end{abstract}

Keywords: Education; Moral; KH. Hasyim Asyari 


\section{Pendahuluan}

Melihat keadaan masyarakat saat ini, tidak dapat dipungkiri bahwa bangsa Indonesia sedang menghadapi dekadensi moral. Dewasa ini, penurunan tingkat moralitas menjadi salah satu problematika di Indonesia. Hal ini dibuktikan dalam penelitian-penelitian yang telah dilakukan antara lain; penelitian Diah Ninggrum (2015) mengenai "Kemerosotan Moral di Kalangan Remaja". Penelitian Eva Indriani (2019) tentang "Modernisasi dan Degradasi Moral Remaja". Penelitian Mochamad Iskarim (2017) mengenai "Dekadensi Moral di Kalangan Pelajar (Revitalisasi Strategi PAI dalam Menumbuhkan Moralitas Generasi Bangsa)". Krisis moral yang juga merambah di bidang pendidikan ini menjadi potret buram dalam dunia pendidikan (Maunah, 2015: 90).

Hal tersebut dapat dilihat dari perilaku siswa yang melakukan kebohongan, kecurangan, tawuran, tidak memiliki rasa hormat kepada orang dewasa, serta bertutur kata tidak sopan dan kasar (Cahyo, 2017: 16). Krisis moral dan etika ini bukan hanya dialami siswa bahkan sekarang guru pun mengalami krisis tersebut. Kasus demi kasus guru yang berbuat tidak senonoh terhadap anak didiknya dapat kita temui di media massa. Hal tersebut dikarenakan kurangnya pengetahuan mengenai makna nilai moral sehingga menyebabkan rusaknya sikap moral yang ada. Kemudian, hal ini sangat berpengaruh besar terhadap perkembangan bangsa Indonesia (Anjarwati, 2020). Disinilah peran pendidikan terutama pendidikan moral sangat dibutuhkan untuk menumbuhkan kembali nilai moral yang telah luntur. Salah satu pemikiran pendidikan yang berkaitan dengan permasalahan di atas ialah persepsi pendidikan KH. Hasyim Asyari. Persepsi ini menitikberatkan pendidikan pada aspek moral atau akhlak.

Penelitian terdahulu yang relevan dengan kajian ini antara lain, penelitian Mashudi (2020) tentang "Pendidikan Moral Perspektif Nilai-Nilai Pemikiran KH. Hasyim As'ari dalam Pendidikan Akhlak". Penelitian Pilo (2019) mengenai "Pemikiran Pendidikan KH. Muhammad Hasyim Asyari”. Penelitian Affandi dan Ulumudin (2020) tentang “Konsep Nilai-Nilai Pemikiran KH. Hasyim As'ari dalam Pendidikan Akhlak". Penelitian Martono (2020) tentang "Pemikiran Pendidikan Islam KH. Hasyim Asyari (Perspektif Epistimologi Sosial Keagamaan dan Konsep Pendidikan Islam bagi Guru dan Peserta Didik)". Penelitian Zuhro (2014) mengenai "Pemikiran Pendidikan Islam 
Menurut KH. Hasyim Asy'ari”. Penelitian Fadli dan Sudrajat (2020) tentang “Keislaman dan Kebangsaan: Telaah Pemikiran KH. Hasyim Asyari”.

Secara umum, penelitian-penelitian tersebut membahas pemikiran pendidikan $\mathrm{KH}$. Hasyim Asyari. Namun, belum spesifik menjelaskan mengenai relevansi antara persepsi pendidikan KH. Hasyim Asyari dengan dekadensi moral yang terjadi saat ini. Oleh karena itu, penelitian ini menjadi sesuatu yang urgensi dan perlu dilakukan dan dibutuhkan penelaahan terhadap bagaimana konsep pendidikan menurut KH. Hasyim Asyari sebagai bentuk pemecahan masalah kemerosotan moral di Indonesia, khususnya di bidang pendidikan.

\section{Metode Penelitian}

Penelitian ini menggunakan metode penelitian studi pustaka, penelitian yang teknik pengumpulan datanya dilakukan dengan pembacaan-pembacaan literatur yang memiliki informasi relevan dengan topik penelitian (Zed, 2004). Selain itu, pendekatan yang digunakan dalam penelitian ini adalah pendekatan kualitatif. Penelitian ini menjadikan bahan pustaka sebagai sumber utama dalam penulisan artikel. Sumber datanya berasal dari publikasi ilmiah berupa artikel, skripsi, makalah dan hasil penelitian lain yang berkaitan dengan fokus penelitian. Ada empat tahapan dari metode studi pustaka yakni menyiapkan perlengkapan alat yang diperlukan, menyiapkan bibliografi kerja, mengorganisasikan waktu, dan membaca serta mencatat bahan penelitian (Zed, 2004).

\section{Pembahasan}

\section{Biografi KH. Hasyim Asyari}

KH. Hasyim Asyari memiliki nama lengkap Muhammad Hasyim Asyari ibn 'Abd al-Wahid ibn 'Abd al-Halim. Beliau lahir di desa Gedang, Jombang, Jawa Timur pada tanggal 14 Februari $1871 \mathrm{M}$ bertepatan dengan 24 Dzulqaidah $1287 \mathrm{H}$. Ibunya bernama Halimah yang merupakan putri kiai Usman, pendiri dan pengasuh pesantren Gedang. Sedangkan ayahnya bernama Asyari, seorang ulama dari Demak dan keturunan ke-8 Jaka Tingkir yang merupakan anak Brawijaya IV salah satu raja Majapahit (Zuhro, 2014: 29). 
Sedari kecil KH. Hasyim Asyari memang merupakan seseorang yang haus akan ilmu. Masa kecilnya dihabiskan dengan menimba ilmu dari pesantren ke pesantren. Beliau diasuh dan dididik oleh ayah, ibu serta kakeknya, kiai Usman yang dikenal sebagai pendidik di pesantren. Sebelum ia berumur enam tahun, ia dirawat oleh kakeknya di Pesantren Gedang. Pada usia 13-14 tahun ia dididik oleh ayahnya dan diberikan kesempatan untuk membantu mengajar di Pesantren Keras yang dipimpin oleh ayahnya sendiri. Kemudian saat menginjak 15 tahun ia mulai menempuh pendidikan di berbagai pesantren. Mulanya ia menjadi santri di Pesantren Wonokoyo Probolinggo, lalu ia pindah ke Pesantren Langitan di Tuban. Setelah itu, ia menimbah ilmu di Pesantren Demangan Bangkalan Madura. Belum merasa cukup dengan ilmunya, beliau akhirnya masuk ke Pesantren Siwalan Surabaya. Pada pesantren inilah beliau dijadikan menantu oleh Kiai Ya'qub, pengasuh pesantren tersebut, dikarenakan kecerdasannya.

Setelah menikah, beliau berangkat ke Mekkah untuk menjalankan ibadah haji sekaligus menuntut ilmu. Ia menetap di Mekkah selama kurang lebih 7 tahun. Di Mekkah, beliau belajar dengan ulama-ulama terkenal, seperti Syaikh Mahfudh alTarmisi, Syaikh Ahmad Khatib Al-Minangkabawy, Syaikh al-Allamah Abdul Hamid alDarutsani, Syaikh Muhammad Syuaib al-Maghribi, Syaikh Ahmad Amin al-Athar, Sayyid Sultan ibn Hasyim, Sayyid Ahmad ibn Hasan al-Attar, Syaikh Sayid Yamay, Sayyid Alawi ibn Ahmad as-Saqaf, Sayyid Abbas Maliki, Sayyid Abdullah al-Zawawy, Syaikh Shaleh Bafadhal dan Syaikh Sultan Hasyim Dagatsani. Disiplin ilmu yang ditekuni KH. Hasyim Asyari selama di Mekkah meliputi fiqh dengan konsentrasi mazhab Syafi'i, ulum al-Hadist, tauhid, tafsir, tasawuf, dan ilmu alat (nahwu, sharaf, mantiq, balaghah, dan lain-lain) (A'dlom, 2014: 16-17).

Pada tahun 1899/1900 KH. Hasyim Asyari memutuskan untuk pulang ke tanah air. Setelah kembali, beliau aktif mengajar di pesantren Gedang dan akhirnya mendirikan pesantren sendiri disekitar daerah Cukir pada tanggal 6 Februari 1906 bernama Pesantren Tebu Ireng. Di pesantren inilah beliau mulai banyak melakukan aktivitas sosial keagamaan dan kemanusiaan, sehingga menjadikannya sebagai pemimpin masyarakat secara informal selain menjadi pemimpin pesantren secara formal. 
Salah satu bentuk aktivitas sosial keagamaan yang dilakukan KH. Hasyim Asyari ialah mendirikan organisasi islam yaitu Nahdlatul Ulama dengan dibantu oleh tokohtokoh Islam tradisional lainnya. Organisasi ini tumbuh dan berkembang sampai akhirnya semakin besar ruang lingkup, pengikut, dan anggotanya. Pada 7 Ramadan 1366 yang bertepatan dengan 25 Juli 1947, KH. Hasyim Asyari meninggal dunia di Tebu Ireng, Jombang, Jawa Timur. Dari riwayat hidupnya, dapat dilihat bahwa beliau merupakan seorang yang haus akan ilmu. Beliau juga banyak menyumbangkan pemikiran-pemikirannya kepada Indonesia.

\section{Persepsi Pendidikan KH. Hasyim Asyari}

Semasa hidupnya KH. Hasyim Asyari juga merupakan seorang penulis yang aktif. Beliau banyak menghasilkan karya yang monumental. Namun, apabila dilihat dari sudut pandang epistemologis kesimpulan dari pemikirannya selalu merujuk pada Al-Quran dan Al-Hadits. Selain itu, karyanya juga memiliki kecenderungan terhadap madzhab syafi'i (Pilo, 2019: 208).

Salah satu karyanya yaitu kitab Adab al Alim wa al Muta'allim, di kitab inilah beliau menuangkan pemikirannya tentang pendidikan terutama mengenai hal yang berkaitan dengan etika orang yang menuntut ilmu dan seorang guru. Secara garis besar kitab tersebut berisikan signifikasi pendidikan, tugas dan tanggung jawab seorang murid, serta tugas dan tanggung jawab seorang guru (Zuhro, 2014: 29).

\section{Signifikasi Pendidikan}

Dalam kitab Adab al Alim wa al Muta'allim KH. Hasyim Asyari memulai penjelasannya dengan kutipan Al-Quran atau Al-Hadits kemudian dijabarkan secara singkat dan jelas. Sebagai contoh, beliau menjelaskan keutamaan menuntut ilmu yang terdapat dalam Al-Quran surat Al-Mujadalah ayat 11. Lalu, beliau kembali menegaskan bahwa keutamaan dari menuntut ilmu adalah mengamalkannya. Hal tersebut dimaksudkan agar ilmu yang telah diperoleh tidak hilang dan bermanfaat di akhirat kelak. KH. Hasyim Asyari juga memaparkan bahwa ada dua poin penting yang harus diperhatikan dalam menuntut ilmu yaitu bagi murid hendaknya menyucikan niat terlebih dahulu serta jangan berniat untuk hal-hal duniawi dan bagi pendidik hendaknya meluruskan niat, jangan semata-mata mengharapkan materi serta berperilaku sesuai dengan yang diajarkan (Affandi dan Ulumudin, 2020: 100). 
Dalam konteks ini, KH. Hasyim Asyari mengartikan pendidikan bukan hanya sebagai penghilang kebodohan atau perantara untuk mendapat materi yang berlimpah semata. Namun, beliau memaknai pendidikan sebagai salah satu bentuk ibadah kepada Allah dengan tujuan akhir mendapatkan ridho serta kebahagian dunia dan akhirat.

\section{Tugas dan Tanggung Jawab Seorang Murid}

KH. Hasyim Asyari dalam kitab Adab al Alim wa al Muta'allim menjelaskan tugas dan tanggung jawab seorang murid sebagai bentuk pendidikan moral atau etika dalam menuntut ilmu. Adapun etika-etika yang harus dipenuhi seorang murid dalam pembelajaran yakni (Mashudi, 2020: 29-31):

\section{a. Etika Siswa Dalam Menuntut Ilmu}

1) Membersihkan hati dari hal-hal yang kotor

2) Memurnikan niat semata-mata karena Allah

3) Tidak menunda-nunda dalam menuntut ilmu

4) Bersikap sabar dan qana'ah terhadap nikmat dan ujian yang diberikan

5) Pandai mengelola waktu

6) Menyederhanakan makan dan minum

7) Bersikap wara' dan berhati-hati dalam berperilaku

8) Meminimalisir makanan dan minuman yang menimbulkan kemalasan

9) Menyedikitkan waktu tidur selama tidak mengganggu kesehatan

10) Menjauhi hal yang tidak berfaedah

\section{b. Etika Siswa Terhadap Guru}

1) Memilih seorang guru dengan memohon kepada Allah dipilihkan guru yang dapat memberikan ilmu serta membina akhlak

2) Percaya dan yakin bahwa guru yang dipilih mempunyai ilmu yang dapat dipercaya

3) Memperhatikan dan menjelaskan apa yang dijelaskan guru

4) Memandang guru dengan kemuliaan

5) Mengetahui hak-hak guru dan senantiasa mendoakannya

6) Bersabar dengan sikap keras guru

7) Duduk dengan sopan dan rapi ketika menghadap guru

8) Berbicara dengan lemah lembut dan sopan kepada guru

9) Mendengarkan semua fatwanya 
10) Tidak menyela pembicaraannya

11) Memakai anggota tubuh sebelah kanan apabila menyerahkan sesuatu kepadanya

\section{c. Etika Murid Dengan Ilmu Pelajarannya}

1) Mendahulukan ilmu yang bersifat fardhu 'ain (wajib) untuk diperlajari

2) Mempelajari ilmu-ilmu pendukung ilmu fardhu 'ain

3) Berhati-hati dan mendiskusikan ikhtilaf (perbedaan pendapat) ulama

4) Mengulas kembali apa yang telah dipelajari kepada guru atau orang yang dipercaya

5) Berpagi-pagi dalam menuntut ilmu

6) Meringkas dan mengulang ilmu yang didapat dengan tekun

7) Berteman dengan orang yang pintar atau lebih tinggi ilmunya

8) Mengucapkan salam ketika sampai di tempat menuntut ilmu

9) Bertanya apabila ada yang tidak dipahami

10) Menunggu giliran dan tidak mendahului teman sebelum mendapat izin apabila sedang dalam keadaan ramai saat menghadap guru

11) Membacakan pelajaran yang telah dipahami kepada guru dengan sikap sopan santun

12) Mempelajari kembali pelajaran secara berkelanjutan

13) Senantiasa menanamkan sikap semangat dalam menuntut ilmu

\section{Tugas dan Tanggung Jawab Seorang Guru}

Dalam kitab Adab al Alim wa al Muta'allim, KH. Hasyim Asyari menguraikan bahwa tidak hanya murid yang mempunyai tugas dan tanggung jawab. Namun, guru pun memiliki tugas dan tanggung jawab dalam pembelajaran. Hampir mirip dengan murid, tugas dan tanggung jawab guru juga dimaknai sebagai moral atau etika yang harus dipenuhi meliputi (Affandi dan Ulumudin, 2020: 103 -204):

\section{a. Etika yang harus Diperhatikan Guru}

1) Selalu mendekatkan diri kepada Allah

2) Senantiasa takut kepada Allah dalam segala keadaan

3) Bersikap tenang

4) Senantiasa besikap wara' dan hati-hati

5) Bersikap tawadhu' (rendah diri) dan khusyu' 
6) Memperhadapkan masalahnya kepada Allah

7) Tidak semata-mata menggunakan ilmu untuk hal yang bersifat keduniawian

8) Tidak selalu memanjakan murid

9) Berperilaku zuhud (melepaskan hati dari pengaruh dunia)

10) Menghindari hal-hal yang hina

11) Menjauhi tempat-tempat maksiat

12) Selalu berusaha untuk tetap di dalam syi'ar islam

13) Senantiasa mengamalkan sunnah Rasulullah

14) Senantiasa berdzikir dan membaca Al-Quran

15) Bersikap ceria, ramah, dan senang menebar salam

16) Menyucikan diri dari perbuatan-perbuatan yang tidak disukai Allah

17) Memupuk semangat untuk memperbanyak ilmu

18) Tidak menyombongkan ilmu dan tidak menyalah gunakannya

19) Membiasakan diri untuk menulis

\section{b. Etika Guru Dalam Mengajar}

1) Membersihkan diri dari hadast dan kotoran

2) Memakai pakai sopan, rapi, dan diusahakan wangi

3) Meniatkan mengajar sebagai sebuah ibadah kepada Allah

4) Menyampaikan hal-hal yang diajarkan Allah

5) Membiasakan diri untuk membaca dan menambah ilmu

6) Mengucapkan salam ketika masuk ke tempat pembelajaran

7) Mendoakan para ahli ilmu yang telah wafat terlebih dahulu

8) Menghindari banyak bergurau dan tertawa

9) Jangan mengajar dalam kondisi lapar, marah, mengantuk, dsb

10) Mengambil posisi yang strategis saat mengajar

11) Menyampaikan ilmu dengan lugas, tegas, ramah, dan tidak sombong

12) Mendahulukan materi-materi yang penting

13) Memperhatikan kemampuan murid

14) Membuat suasana yang kondusif

15) Tidak mengeraskan suara apabila tidak dibutuhkan

16) Bersikap terbuka terhadap permasalahan yang ditemukan 
17) Memberi kesempatan kepada murid yang terlambat dengan mengulangi pelajaran

18) Memberikan peluang untuk bertanya bagi murid yang belum paham

\section{c. Etika Guru Bersama Murid}

1) Meniatkan mengajar dan belajar hanya karena Allah

2) Berniat menyebarkan ilmu untuk menghidupkan syariat islam

3) Mencintai murid

4) Menggunakan metode yang tepat dalam mengajar

5) Memotivasi murid untuk membangkitkan semangatnya

6) Memberikan latihan-latihan yang bersifat membantu

7) Memperhatikan kemampuan setiap murid

8) Menyamaratakan dan tidak pilih kasih terhadap murid

9) Mengarahkan minat dan bakat murid

10) Senantiasa bersikap terbuka dan lapang dada

11) Memberikan cinta kasih kepada murid yang hadir, mencari kabar murid yang tidak hadir

12) Membantu memecahkan masalah dan kesulitan yang dihadapi murid

13) Bersikap arif, tawadhu, dan bijaksana terhadap murid

\section{Persepsi Pendidikan KH. Hasyim Asyari Dalam Pemecahan Masalah Dekadensi}

\section{Moral}

Dalam menanggulangi problem penurunan tingkat moralitas, pendidikan moral dapat menjadi salah satu solusi yang dapat digunakan. Pendidikan moral secara sederhana diartikan sebagai upaya yang dirancang secara sengaja untuk memperbaiki karakter siswa (Samani dan Hariyanto, 2013: 44). Hal tersebut sejalan dengan persepsi pendidikan KH. Hasyim Asyari yang mengutamakan pendidikan moral. Dengan demikian, persepsi tersebut dapat diimplementasikan sebagai penyelesain persoalan dekadensi moral yang terjadi. Nilai-nilai moral dari buah pemikiran KH. Hasyim Asyari harus melekat dan dijiwai oleh setiap subjek dan objek pendidikan agar nantinya tercapai tujuan pendidikan sehingga dapat membantu perkembangan negara Indonesia. 
Relasi antara guru dengan murid merupakan hubungan edukatif yang terjadi diikat oleh sejumlah norma sebagai medianya untuk mencapai tujuan belajar bersama. Dalam konteks ini KH. Hasyim Asy'ari telah memberikan penilaian yang tajam pada guru dan murid. Pendidikan harus dipandang merupakan hubungan antara guru dan murid. Sebagai seorang tokoh ulama dan pendidik yang disegani, KH. Hasyim Asy'ari, memiliki peran dan pengaruh yang besar di Indonesia sekaligus merupakan tokoh pendidikan Islam yang memiliki banyak kontribusi dalam membangun moral pada peserta didik/santrinya. KH. Hasyim Asy'ari menekanan pentingnya perbaikan moral spiritual melalui suri tauladan seorang guru melalui penanaman nilai-nilai moral pada para peserta didik. Menekankan sikap hormat dan menjauhkan diri dari hawa nafsu serta menyadarkan bahwa pendidik dan peserta didik harus selalu bertautan dengan Allah SWT dalam setiap aktivitas pembelajaran (Ni'mah, 2019).

Prinsip-prinsip di atas penting untuk diimplementasikan dalam pendidikan saat ini ditengah kemajuan teknologi dan informasi yang kadang banyak membawa hal-hal yang negatif pada dunia pendidikan. Guru daalam persepsi KH. Hasyim Asy'ari harus menjadi teladan yang utuh bagi anak didiknya, memiliki kepribadian dan intelektual yang berkarakter dan shalih, konsisten dengan amanahnya, memiliki semangat bahwa mengajar adalah ibadah. Menjunjung norma kemasyarakatan dengan baik dan berperan di lingkungan masyarakat menjadi suatu kewajiban dan tanggung jawab, militan, bersikap bijak dan arif, menjaga kebersihan, kesehatan, dan stamina, serta mengajar secara totalitas setiap waktu menjadi modal utama dalam membangun dunia pendidikan yang berkualitas. Bagi KH. Hasyim Asy'ari seorang murid seharusnya selalu berusaha membersihkan hati dari hawa nafsunya. Memiliki target dalam setiap jenjang pendidikan yang ditempuh merupakan keharusan jika ingin berhasil, konsisten belajar dan niat yang tulus karena Allah SWT dalam mencari ilmu yang barokah dan bermanfaat. Selalu berusaha maksimal dalam menggunakan waktu belajar, memelihara sikap sederhana dengan tidak konsumtif selama menempuh pendidikan. Terpenting dari semua itu adalah menjaga hubungan kekeluargaan dan kasih sayang dengan guru dan sesama (Ni'mah, 2019).

Relasi seorang guru dan murid harus berjalan secara harmonis sesuai dengan tanggung jawab masing-masing dengan menumbuhkan sikap tulus dan rendah hati. Guru memiliki sikap dan bertanggung jawab dalam memberikan suri tauladan, kasih 
sayang tinggi kepada para murid dan berkarakter humanis. Peserta didik harus menghormati para guru dalam setiap tahap dan proses pembelajaran yang diikuti, hangat pada pada guru dan rekan-rekannya (Waqfin, 2020). Dalam konteks ini peserta didik juga berperan dalam menilai guru, menghormati dan tidak menyinggung perasaan guru sebagai pribadi yang telah mengajarkan ilmu pengetahuan. Membangun relasi kedekatan dengan guru tanpa pamrih dan tidak berpaling dari guru dalam suasan apapun.

\section{Kesimpulan}

Persepsi pendidikan KH. Hasyim Asyari tertuang di salah satu karya monumentalnya yaitu kitab Adab al Alim wa al Muta'allim. Secara keseluruhan kitab ini berisi signifikasi pendidikan, tugas dan tanggung jawab seorang murid, serta tugas dan tanggung jawab seorang guru. Dalam hal ini, tugas dan tanggung jawab murid maupun guru diterjemahkan sebagai pendidikan moral yang harus dipenuhi saat pembelajaran. Kemudian, dapat ditarik kesimpulan bahwa pemikiran KH. Hasyim Asyari dalam bidang pendidikan berorientasi kepada pendidikan moral atau etika. Oleh karena itu, pengimplementasian nilai-nilai moral yang tertanam pada persepsi pendidikan ini dapat menjadi salah satu jalan keluar dari persoalan kemerosotan nilai moral di Indonesia.

\section{Daftar Rujukan}

A'dlom, Syamsul. (2014). Kiprah KH. Hasyim Asyari dalam Mengembangkan Pendidikan Agama Islam. Jurnal Pusaka, 3 (2): 14-26.

Affandi, Abdullah dan Ulumudin, Moch. Ihyak. (2020). Konsep Nilai-Nilai Pemikiran KH. Hasyim As'ari dalam Pendidikan Akhlak. Jurnal Al-Hikmah, 8 (1): 21-40.

Anjarwati, Widya. (2020). Minimnya Nilai Moral dikalangan Masyarakat pada Masa Modern. Makalah tidak dipublikasikan, Madiun: Universitas Katolik Widya Mandala.

Cahyo, Edo Dwi. (2017). Pendidikan Karakter Guna Menanggulangi Dekadensi Moral yang Terjadi pada Siswa Sekolah Dasar. Jurnal Edu Humaniora: Jurnal Pendidikan Dasar, 9 (1): 16-26. 
Fadli, Muhammad Rijal dan Sudrajat, Ajat. (2020). Keislaman dan Kebangsaan: Telaah Pemikiran KH. Hasyim Asyari. Jurnal Khazanah: Jurnal Studi Islam dan Humaniora, 18 (1): 110-130.

Indriani, Eva. (2019). Modernisasi dan Degradasi Moral Remaja. Skripsi tidak dipublikasikan. Lampung: Universitas Islam Negeri Raden Intan.

Iskarim, M. (2017). Dekadensi Moral di Kalangan Pelajar (Revitalisasi Strategi PAI dalam Menumbuhkan Moralitas Generasi Bangsa). Edukasia Islamika, 1-20.

Martono. (2020). Pemikiran Pendidikan Islam KH. Hasyim Asyari (Perspektif Epistimologi Sosial Keagamaan dan Konsep Pendidikan Islam bagi Guru dan Peserta Didik). Jurnal Al-Fikr : Jurnal Pendidikan Islam, 6 (1): 40-45.

Mashudi, Moh. (2020). Pendidikan Moral Perspektif Nilai-Nilai Pemikiran KH. Hasyim As'ari dalam Pendidikan Akhlak. Jurnal Al-Hikmah, 8 (1): 21-40.

Maunah, Binti. (2015). Implementasi Pendidikan Karakter dalam Pembentukan Kepribadian Holistik Siswa. Jurnal Pendidikan Karakter, 5 (1): 90-101.

Ni'mah, D. H. (2019). Relasi guru dengan murid perspektif KH. Hasyim Asy’ari dalam kitab Adab al 'Alim wa al Muta'allim. Tesis. Surabaya: UIN Sunan Ampel Surabaya.

Ninggrum, Diah. (2015). Kemerosotan Moral di Kalangan Remaja: Sebuah penelitian Mengenai Parenting Styles dan Pengajaran Adab. Jurnal UNISIA, 37(82): 18-30.

Pilo, Nashiruddin. (2019). Pemikiran Pendidikan KH. Muhammad Hasyim Asyari. Jurnal Ilmiah Islamic Resources, 16 (2): 205-221.

Samani, Muchlas dan Hariyanto. (2013). Pendidikan Karakter. Bandung: Remaja Rosdakarya.

Waqfin, S. I. (2020). Manajemen Pendidikan Akhlaq Dalam Mengantisipasi Dekadensi Moral Siswa. JoEMS (Journal of Education and Management Studies), 3(2), 49-56.

Zed, Mestika. (2004). Metode Penelitian Kepustakaan. Jakarta: Yayasan Pustaka Obor Indonesia.

Zuhro, Fatimatuz. (2014). Pemikiran Pendidikan Islam Menurut KH. Hasyim Asy'ari. Skripsi (tidak dipublikasikan). Malang: Universitas Islam Negeri Maulana Malik Ibrahim. 